\title{
Sacro e profano na música
}

\author{
Thrasybulos Georgiades (1907-1977) \\ Igor Baggio (tradução e notas) \\ Pesquisador independente \\ igor_baggio@hotmail.com \\ https://orcid.org/0000-0002-4974-716X
}

Resumo: Thrasybulos Georgiades foi um dos mais importantes musicólogos alemães do século passado, mas ainda não é bem conhecido em nosso país. Suas pesquisas centraram-se na relação entre música e linguagem através da história da música ocidental, da Grécia antiga até a modernidade. $\mathrm{O}$ texto, cuja tradução do alemão apresentamos aqui, foi uma palestra por ocasião da comemoração do quadringentésimo octogésimo oitavo $\left(488^{\circ}\right)$ aniversário de fundação da Ludwig-Maximilians-Universität de Munique, na Alemanha, em 25 de junho de 1960. Publicado pela primeira vez, neste mesmo ano, como o Neue Folge Heft 28, na série Münchener Universitätsreden pela Editora Max Hueber de Munique. Aparece, posteriormente e inalterado, no volume Kleine Schriften, coletânea de ensaios e trabalhos de Georgiades publicada em janeiro de 1977 pela Editora Hans Schneider de Tutzing, por ocasião do $70^{\circ}$ aniversário do autor, que viria a falecer em março daquele mesmo ano. Trata-se de um texto no qual Georgiades reflete brevemente sobre a modificação essencial que a relação entre música e linguagem sofre no interior do processo de secularização crescente da música ocidental ao longo de sua história. Pode ser entendido, também, como um texto que introduz o leitor ao cerne de seu pensamento musicológico.

Palavras-chave: Thrasybulos Georgiades (1907-1977), História da música ocidental, Música e linguagem, Música sacra, Música profana.

\section{Sacred and Profane in Music}

Abstract: Thrasybulos Georgiades was one of the most important German musicologists of the Twentieth Century, but he still isn't well known in our country. His researches are centered in music' relationships with language along history, from ancient Greece until modernity. The text that is translated here from the German to Portuguese was originally a speech delivered by Georgiades on the occasion of the $488^{\circ}$ foundation anniversary of the Ludwig-Maximilians-Universität in Munich, in the Sixties. The text appeared later, in 1977, in Georgiade's Kleine Schriften, a collection of his best essays. It is a text that serves well as an introduction to Georgiades musicological work by treating the essential changes that affected the relationship among music and language along the history of Western Music, a history that is reflected in the text as a process of increasing secularization. The text can also be read as an introduction to the central issue of his musicological thought.

Keywords: Thrasybulos Georgiades (1907-1977), Western Music History, Music and Language, Sacred Music, Profane Music.

\section{Thrasybulos Georgiades: uma breve apresentação}

Musicólogo nascido em Atenas na Grécia em 1907, Georgiades fez seus estudos superiores em música na Alemanha, aonde viria a se estabelecer como um dos principais musicólogos do período do pós-guerra. Seu trabalho de habilitação (Habilitation), sobre a influência da rítmica e da métrica quantitativa do grego antigo e da música grega antiga 
nas origens da música ocidental foi defendido em 1947, sob a orientação do musicólogo Rudolf von Ficker, na Universidade de Munique. A partir de 1948, Georgiades passa a lecionar musicologia na Universidade de Heidelberg, onde é apontado diretor do departamento de musicologia em 1949 e professor titular em 1955. Em 1956, Georgiades é apontado como professor de musicologia na Universidade de Munique, posto onde permaneceu até sua aposentadoria em 1972.

Seu principal interesse de pesquisa pode ser tomado como tendo sido a relação entre música e linguagem ao longo da história da música ocidental. Seu livro mais conhecido, Musik und Sprache: das Werden der abendländischen Musik dargestellt an der Vertonung der Messe, publicado originalmente em 1954, constitui uma contribuição teórico-musicológica e histórico-filosófica original tendo em vista a problemática do devir histórico da música ocidental em direção a sua autonomia com relação à linguagem verbal na modernidade. Em termos simplificados, podemos dizer que uma das teses centrais de Georgiades é a de que o significado histórico-filosófico da autonomia que a música instrumental - e mesmo a música vocal - conquistou com relação à palavra ao longo da modernidade se dá a partir de seu contato com as línguas vernáculas, no caso aqui, com a língua alemã, cujas especificidades sonoras e estruturais o autor analisará como fundamentais para a música ocidental a partir de Schütz, Bach e, notadamente, os clássicos vienenses.

Para Georgiades, essa autonomização só se torna plenamente compreensível ao apreciarmos a especificidade dos regimes particulares de determinação da música pela linguagem verbal desde a Idade Média até o Renascimento, período no qual o latim determinava outro regime de relação entre música e linguagem, um regime no qual não era possível à música afastar-se da estrutura rígida da língua eclesiástica e da pretensão sacramental e teológica da palavra - pelo menos no interior da música religiosa. O método escolhido por Georgiades para expor sua tese a respeito do corte histórico operado na relação entre a música e a linguagem verbal a partir, principalmente, de J. S. Bach e os clássicos vienenses é, ao mesmo tempo, analítico-comparativo e histórico-filosófico. Como o título de seu livro explicita, trata-se ali de acompanhar as modificações no relacionamento da música com a palavra ao longo da história a partir de um único gênero, a Missa, cujo texto em latim (o texto do "Ordinário" da Missa) permaneceu o mesmo ao longo do período estudado. O texto de que oferecemos a tradução para o português aqui 
pode ser entendido tanto como um resumo, quanto como um detalhamento que expande pontos cruciais do trabalho realizado por Georgiades em Musik und Sprache e em outros trabalhos. Ao focar aqui em uma interpretação de como teria se estabelecido a relação entre a música cristã ocidental e a linguagem ao longo da Idade Média europeia, Georgiades alcança uma visão sinóptica de cunho histórico-filosófico de toda a evolução posterior da história da música ocidental. É sempre na relação com a palavra que a história da música é interpretada pelo musicólogo, como refletindo um processo duplo: inicialmente, a partir da época carolíngea, no século IX, e ao longo da Idade Média, como um processo de sacralização da música pela linguagem, processo cujo apogeu se dá no ideal a capella de Palestrina e Lassus no Renascimento. A partir do barroco alemão e, posteriormente, ao longo da modernidade, o processo passa a ser de secularização e de instrumentalização da música sacra pela música instrumental autônoma, porém, sempre sob a sombra da relação pregressa que havia se dado no interior da música sacra. Ou seja, teria sido apenas através do contato com a palavra com pretensões sacras ao longo da história que a música instrumental autônoma teria aprendido a se assemelhar, por si só, à linguagem e, ao fim e ao cabo, emergir historicamente como uma forma de linguagem. Para uma introdução mais detalhada sobre a pesquisa musicológica e o pensamento musical de Georgiades, inclusive suas proposições fenomenológicas de maturidade em seu livro póstumo de 1985, Nennen und Erklingen. Die Zeit als Logos, que seguem de perto e aprofundam questões presentes no texto aqui traduzido, cf. Pelinski (2015).

O tradutor gostaria de agradecer a Cintia Alves, pela revisão da tradução do alemão para o português. 


\section{Sacro e profano na música}

Dois pontos de vista contraditórios entre si permitem à música manifestar-se como fenômeno isolado, como forma sonora, ou como algo enraizado na unidade do humano. O tema "sacro e profano na música" coloca essas duas maneiras de considerá-la em relação recíproca.

Nós queremos nos limitar [aqui] aos domínios do ocidente cristão, queremos, portanto, nos apoiar naquilo que trazemos como música em nós: a totalidade da música em nossa história cristã-ocidental ${ }^{1}$.

Por música sacra entendemos aquela ligada ao culto. O domínio da música religiosa $(\text { geistlich })^{2}$ vai mais longe, ele compreende não apenas a música sacra, mas também, por exemplo, a música de devoção pessoal ou uma canção de igreja. Sua delimitação para com a música secular (weltliche) ${ }^{3}$ é, consequentemente, menos clara. No entanto, a delimitação tanto da música sacra como também da música religiosa em relação à secular mostra-se somente na função das obras. A partir do feitio $(\text { Faktur })^{4}$ musical não é possível estabelecer uma clara distinção entre a execução de obras sacras (sakralen), e respectivamente das religiosas, e das seculares.

Isso fica evidente através da confrontação seja de uma missa de Palestrina com um madrigal secular daquela época, seja de uma ópera de Mozart com uma de suas missas,

\footnotetext{
${ }^{1} \mathrm{O}$ estilo quase coloquial de passagens como a deste parágrafo e a própria estrutura, por vezes esquemática, do texto como um todo, se deve ao fato do mesmo ser, como já dito em nota acima, o de uma palestra apresentada oralmente. O uso reiterado de palavras italicizadas no texto parece derivar da ênfase oral pretendida pelo autor em sua apresentação. O início do texto versará especificamente sobre a música da Idade Média, a partir do século IX. Mais especificamente, Georgiades visará apreciar como teria se estabelecido a relação entre a música e a palavra nesse contexto medieval, referindo-se à relação entre o que ele chamará de "elemento sacro" e "elemento profano da música". Para a tradução, quando se julgou que o termo em português escolhido não cobria totalmente o sentido do termo original alemão, optou-se por manter este último entre parênteses.

${ }^{2}$ Devido ao teor da discussão levada a cabo pelo texto, preferiu-se traduzir o adjetivo geistlich aqui não como espiritual, mas sim, seguindo seu sentido historicamente marcado, como religioso (no âmbito do cristianismo). Isso se deu devido ao fato do contexto de onde é extraída sua utilização aqui ser o da música medieval europeia, no qual o autor visa situar a origem da oposição entre o elemento sacro, e especificamente religioso, e o elemento profano da música.

${ }^{3}$ Apesar de weltlich poder ser traduzido em diversos momentos do texto, sem prejuízo de sentido, como profano, para evitarmos confusão com o uso dado por Georgiades aos sinônimos profan e weltlich, preferimos traduzir aqui weltich sempre como secular, reservando-se o termo profano para traduzir o alemão profan.

${ }^{4}$ Feitio referindo-se à maneira com que a música está feita, com especial atenção à sua estrutura interna e/ou sua textura sonora sensível.
} 
ou com seu Réquiem; ou ainda, de um canto tirolês secular (weltlichen Jodlers) com outro devocional, cantados na igreja. Pode ser que uma obra religiosa (geistlich) até seja avaliada como séria, e que exija uma exposição mais prudente que uma obra secular. No entanto, o feitio musical é essencialmente o mesmo, em ambos os casos. Assim, é possível elucidar também que a música secular pôde ser assumida pela igreja em épocas pretéritas. Era costume, ainda por J. S. Bach, por exemplo, no lugar de um texto lírico secular, substituí-lo por um religioso e, desse modo, se metamorfoseava uma composição secular em sacra. - Que o divórcio entre obras religiosas e seculares é quase impossível, tornase ainda mais claro quando nós pensamos num "gênero hermafrodita" (Zwittergattung) como o Oratório. Um oratório sacro de Händel diferencia-se de um secular somente por seu teor (Inhalt). - Não o momento musical em si, mas o teor, o caráter (Gesinnung), a atitude (Einstellung), o propósito a que a música intenta é que definem a obra musical como sacra ou secular. Por esta razão, eu não quero falar sobre obras musicais sacras ou profanas - ou religiosas e seculares -, mas sim sobre o elemento ${ }^{5}$ sacro e profano na música.

A palavra latina pro-fanus $^{6}$ significa: estar fora dos círculos sagrados. Profano é o não abençoado, o aind $a^{7}$ não consagrado, o ainda não inscrito no espaço do sagrado. Ele pode vir a ser sacro, quando for incluído, quando for consagrado. Sagrado é o abençoado, consagrado. O que é, então, o profano, em si? Ele é o mundo natural: a natureza, o ser humano natural. Tudo é primeiramente profano, na medida em que precisa tornar-se abençoado, ser consagrado, para tornar-se sacro. Apenas uma coisa pode, por si só, ser genuinamente sacra: o consagrado (das Weihende). Mas então o que é isto? Isto é a palavra, apenas a palavra. O profano torna-se abençoado, consagrado, sempre através "do Nome", através da palavra nomeadora, através da palavra como fenômeno-originário (Urphänomen) do humano e, por conseguinte, do religioso. Nenhuma ação pode, por si só, consagrar-se de forma autônoma, muda; ela precisa da palavra sacra, consagradora.

Pão, vinho, água, fogo, vela são naturalmente interpretados como profanos. Mas através da palavra sacra eles podem consagrar-se, tornarem-se sacros, manifestarem-se com uma função sacra. Além disso, todas as coisas naturais e os processos vitais, por

\footnotetext{
${ }^{5}$ Grifo no original.

${ }^{6}$ Grafia e grifo no original.

${ }^{7}$ Grifo no original.
} 
exemplo, a dança, a colheita, o casamento podem ser abençoados e novamente reenviados ao mundo. Elas são, portanto, seculares, mas não mais profanas: o pão eucarístico possui uma função sacra. Mas também o pão de cada dia, como alimento, mantém de fato o homem em uma cultura, por assim dizer, enraizada pela Religião, não diretamente pelo padeiro, mas através da Igreja. - O profano, o mundo natural é, portanto, da perspectiva do sacro, a matéria bruta. Todavia, o secular precede o sagrado e o consagrado.

De modo semelhante comporta-se com a música. Considerada isoladamente, como mera matéria bruta, ela é profana. Primeiramente, é através da palavra que ela se torna música sacra. E esta configura também a pré-condição para o surgimento de uma música secular $^{8}$ consagrada, ainda que não sacra. - O que acabo de dizer oferece a chave para o entendimento da música ocidental. Nossa música historicamente formada foi marcada por intermédio da palavra sacra. Através da palavra sacra, no decorrer dos séculos, ela foi prefigurada, antes de tudo, como música sacra, e este suporte de sentido (Sinnträger), assim formado, trouxe consigo também obras seculares ${ }^{9}$, não sacras à tona ${ }^{10}$. Esse estado de coisas alterou-se pela primeira vez com o início do século XIX burguês; de uma perspectiva musical, com a morte de Beethoven. - O que aconteceu depois disso? E onde estamos hoje? Essas questões nós colocamos em um ponto anterior ${ }^{11}$.

Permaneçamos na questão: como surge a música sacra, como a palavra sacra traz à tona a música sacra? - Uma vez agregada a palavra, ela será repetidamente evocada. Através de sua dupla característica, como nomeadora e perceptível (vernehmbar) ela forja uma comunidade sob a influência do fato religioso. Mas como se torna audível, afinal, a linguagem sacra nessa comunidade? A resposta: "através da fala ou através do canto" não basta. Pois o limite (die Grenze) entre a fala e o canto não é nítida, e, além disso, dependendo da linguagem subjacente, ela deve ser traçada de forma diferente. Assim, é sensato constatar apenas que a linguagem ressoa $^{12}$ (erklingt) no culto ${ }^{13}$. No entanto, ela

\footnotetext{
${ }^{8}$ Grifo no original.

${ }^{9}$ Grifo no original.

${ }^{10}$ Pouco clara é a origem da música secular polifônica do trecento italiano, a qual se afigura, entretanto, um ramo especial. [N.A.]

${ }^{11}$ Provável referência ao texto Musiksprache der Wiener Klassiker, escrito por Georgiades em 1955 e que também consta da coletânea Kleine Schriften.

${ }^{12}$ Grifo no original.

${ }^{13}$ A distinção destas duas propriedades da palavra, o nomear (nennen) e o ressoar (erklingen) constitui o fundamento fenomenológico da pesquisa de maturidade de Georgiades, que se encontra no livro póstumo de 1985, intitulado justamente Nennen und erklingen. Die Zeit als Logos.
} 
ressoa dentro de uma comunidade, e não como um meio de entendimento habitual sob os homens, portanto, como algo não natural, como linguagem usual. Esta "não" é a porta de entrada da música, mais precisamente: do componente musical. Chamemos a linguagem do ressoar não natural-cotidiano (die nicht altäglich-natürlich erklingende Sprache) de “canto". O canto uníssono no culto, assim entendido, está, também, estreitamente entrosado com a linguagem, a linguagem enquanto ressoar. Por isso, tão pouco a linguagem é idêntica com aquilo que em tempos posteriores entendia-se sob a arte autônoma, tão pouco é isto, também, o canto no culto. Ele também não é uma "arte servil", mas sim uma face $^{14}$ necessária do culto.

Para a fala a voz, a voz sonora, não é estritamente necessária. Pode-se sussurrar e ainda assim falar-se de maneira audível. Necessária é apenas a articulação. Esta é exclusiva e imediatamente singular à humanidade. Entre articulação e pessoa não há mediações. Contudo, no ressoar da palavra sacra enquanto canto emerge um momento, momento esse que não é dedutível somente através da linguagem. O canto sem voz sonora não é possível. Entre o canto e a pessoa dá-se a mediação da sonoridade (der Ton), um terceiro, um algo - um algo que não é especificamente humano: a natureza, os seres vivos, os instrumentos também podem sonorizar. É por isso que a linguagem (die Sprache) nua é o imediato, de fato, o único modo de aparição dos fatos religiosos sem mediação e, por conseguinte, da pessoa; assim sucede a domesticação (Bändigung) do intelectual (Geistigem) através do canto, primeiro através da utilização de uma matéria, do som, igualmente e primeiramente através da encarnação (Verkörperung), e da objetivação (Vergegenständlichung). Este momento da sonorização, que é necessário e igualmente característico para o canto, e não para a fala, realiza a transformação da fala nua (como na expressão da pessoa) no canto, como a encarnação sonora da comunidade.

Assim surge o canto litúrgico uníssono (que no âmbito da igreja católica conhecemos como canto gregoriano, na igreja grego-ortodoxa como canto da igreja bizantina). O som é aqui intimamente amalgamado (innig verquickt) com a palavra sacra; ele entra em cena simultânea e necessariamente com ela. Nesse ponto, é possível observar o elemento musical no canto litúrgico uníssono como primariamente sacro.

\footnotetext{
${ }^{14}$ Grifo no original.
} 
Qual é, então, o elemento profano primário na música? É aquele, o qual não tem elemento necessário, que não configura nenhuma parte integradora ao ressoar da palavra sacra. Ele aparece a nós, portanto, lá onde a música aparece por si só. Tal música é a polifônica e, particularmente, a instrumental, aquela música independente da linguagem. (Os "pais" da igreja voltaram-se contra a utilização de instrumentos). O ressoar dos instrumentos não é nenhuma denominação, nenhum falar, como o canto uníssono, senão que se torna essencialmente determinado pelo tocar, pela execução (Spiel). O canto não se pode indicar pela execução. Mas um instrumento "executa-se", toca-se".

A polifonia é intimamente aparentada com o instrumental. Ela ocorre mais naturalmente com o tocar conjunto de vários instrumentos. $\mathrm{E}$ ambos, o instrumental e o elemento polifônico garantem sua autonomia musical. O instrumental-polifônico (Mehrstimmig-Instrumentale) é o elemento profano primário da música. Ele pode ${ }^{15}$ ser incluído no domínio sacro, ele pode ser consagrado e estar em uma missa como elemento ligado à linguagem, ou também aparecer como pura música instrumental.

Há várias razões que contribuem para a afirmação de que a música nórdica introduzida em igrejas cristãs de povos germânicos era baseada em sons simultâneos (Zusammenklängen) e utilizava instrumentos, quer dizer, que essa música possuía um feitio (Faktur) instrumental-polifônico. Nesse contexto associam-se os registros de polifonia encontrados na igreja cristã da época carolíngia, no século IX. (Nós sabemos que essa antiga polifonia cristã se utilizava de instrumentos.) Esse acontecimento do início do uso do instrumental-polifônico no domínio do sacro-cristão significou o começo, propriamente falando, da música ocidental. Com isso, estabelecia-se a tensão entre o elemento sacro e o profano, que daí em diante fecundou de forma determinante nossa música.

A música instrumental-polifônica dos povos nórdicos ainda era uma matériaprima, como um novelo embaraçado, ainda não desvendado historicamente. O processo de consagração desses elementos musicais profanos através da palavra sacra é, como já afirmei, o processo histórico de nossa música. O mediador é o canto litúrgico uníssono. Toda a antiga música sacra polifônica baseou-se nele. Ela não é nada mais do que uma elaboração polifônica do canto litúrgico. - Através do encontro do canto litúrgico com o

\footnotetext{
${ }^{15}$ Grifo no original.
} 
profano, com o elemento instrumental-polifônico, iniciou a constante polêmica entre a linguagem, mais precisamente a linguagem $s a c r a^{16}$, e a música autônoma (eigenständiger Musik) - uma polêmica que se transformou no fermento para o devir da música ocidental. No decurso dos séculos, da linguagem a música polifônica aprendeu a articulação, ela tornou-se semelhante à linguagem. Entretanto, na linguagem, enquanto fenômeno original da humanidade revela-se o próprio homem; ele se representando a si mesmo. A linguagem é - assim podemos dizer $-a^{17}$ representação primária da humanidade. Se compararmos a música profana instrumental-polifônica da época carolíngea com uma "faixa ornamental" (Bandornament), o processo do devir da música ocidental polifônica aparece como o processo de sua metamorfose de ornamento em representação da humanidade.

O processo durou do século IX até o início do século XIX, incluindo até o Classicismo Vienense. - Na época da Contrarreforma e do Concílio de Trento, no século XVI, pôde a música, com Palestrina e Orlando di Lasso, pela primeira vez se despir do caráter ornamental. Então, pela primeira vez a estrutura dessa música polifônica recobriuse inteiramente com a estrutura do sacro, da língua latina. É notável que agora se eliminavam os instrumentos, que se executava a música de forma puramente vocal.

Todavia, a Reforma deu um novo impulso. Ela introduziu a língua alemã e introduziu, com isso, um novo domínio religioso nos domínios até então profanos. $\mathrm{O}$ idioma alemão une-se à música sacra-polifônica previamente encontrada e a transforma. A partir disso, emerge a música de Heinrich Schütz, no século XVII. A sua estrutura recobre-se também com a estrutura da linguagem, que agora, então, era a alema ${ }^{18}$. Como música, ela apresenta-se à humanidade por um lado novo, um lado até então não imaginado.

Com J. S. Bach transfigura-se a música mais uma vez. Tendo sido ela até então orientada pela linguagem, de Bach em diante, mesmo enquanto linguagem, ela passou a ser concebida instrumentalmente. Agora a música, carregada de sentido através da centenária aprendizagem junto à linguagem, seria igualmente autônoma. Agora a música - também a música instrumental - articulava, como se ela mesma falasse. Mas lembremo-

\footnotetext{
${ }^{16}$ Grifo no original.

${ }^{17}$ Grifo no original.

${ }^{18}$ Grifo no original.
} 
nos que o instrumental-polifônico é o elemento profano $^{19}$. Este que, através de Bach, torna-se o meio significante central, especialmente para a afirmação religiosa, e que com a entrada da herança da música que até então se apresentava ligada à linguagem, foi consagrado. Por esta razão, essa metamorfose da música não significou um retrocesso ao profano, mas, ao contrário, um enriquecimento e um aprofundamento do musicalreligioso.

Mas o que ocorreu com a música secular, que, enquanto isso, tornou-se poderosa através da ópera e da música instrumental autônoma? Nós já vimos que a partir do feitio nenhuma separação entre obras religiosas e seculares é alcançável. Agora acrescentamos: na época mais antiga o feitio era determinado pela música sacra, mas de agora em diante é o inverso: o feitio secular da música influenciará de forma decisiva também a religiosa. Porém, esse novo meio significante musical secular (nеue weltliche musikalische Sinnträger) pressupõe ainda - apesar da inclusão de novos elementos, pode-se dizer, ainda não consagrados - a polêmica travada nos séculos passados com a palavra sagrada; pois ele carrega os traços de sua origem, tem memória histórica e permanece, desse modo, consagrado.

Os clássicos vienenses, Haydn, Mozart e Beethoven vieram desta música secular. Porém eles a fundiram, novamente, com a instrumental, que (por Bach) já havia sido fertilizada com a grande tradição da música sacra ocidental. Sob as mãos dos clássicos vienenses tornou-se o meio significante instrumental todo poderoso, e com isso a tensão entre o profano e o sagrado alcançou seu ápice no contexto de nossa história. Aí se assenta a grandeza da música clássica vienense. A tendência determinante no devir da música ocidental desde a época carolíngia era abranger cada vez mais o território do profano, incorporá-lo como meio significante musical originalmente moldado pela palavra sacra e, assim, enriquecer, expandir e aprofundar a música. Os clássicos vienenses consumaram esse último passo: eles transformaram o especificamente religioso (Geistliche), ancorado no mais profundo cristianismo, em algo universalmente espiritual (AllgemeinGeistiges) ${ }^{20}$. A música dos clássicos vienenses tinha um caráter notadamente secular-

\footnotetext{
${ }^{19}$ Grifo no original.

${ }^{20}$ Grifos no original.
} 
intelectual (weltlich-geistiges). Vamos nos ater um pouco junto à questão: como se manifesta a atitude secular?

A música dos clássicos vienenses pode rir, ela pode rir de seus objetos. Isso fica especialmente evidente nas óperas de Mozart, mas também se aplica, por exemplo, para a música instrumental de Haydn. - Nas obras espirituais de Schütz ou de Bach falta esse impulso. Seria isso um defeito? - Eu acredito que essa observação fornece um princípio para entender o que diferencia a arte secular da religiosa.

Secular é a obra de Shakespeare. Ela assinala ainda mais claramente que a música do classicismo vienense o lugar central do humor, sobretudo o rir do ser humano sobre si próprio por levar-se a sério demais, por ele permanecer preso em sua tolice (Torheit). Isso não acontece apenas através da figura do tolo, mas em todo lugar. Pensem, por exemplo, na cena do coveiro em Hamlet. Ou então - para apontar um exemplo da pintura - pensem em um quadro como "A queda de Ícaro" de Breughel [sic] ${ }^{21}$ : Ícaro, um ser humano diminuto, quase na borda da moldura do quadro, despenca no mar, sem que o mundo, imerso em uma paisagem pacífica, se desse conta do acontecido.

Mas esse conhecimento do que diz respeito à debilidade, à tolice, só é possível se ele se desvincular, como um lampejo, do conhecimento de algo diferente, essencial, inalterável, e se posicione em relação a esse algo. Dito de outro modo: em um único ser está o conhecimento sobre a dignidade de um momento e sobre sua fugacidade. Isso equivale a dizer que o secular consagrado em nossa história é, portanto, cristão. O saber sobre o fato religioso permanece, no caso, impronunciado, porém está presente.

A obra religiosa de Schütz ou de Bach se encontra para além dessa problemática. Ela foca expressivamente o âmbito do existente (des Seienden), do permanente (des Bleibenden). Aqui a fratura do olhar por intermédio do que é do lado de cá, do que é passageiro (Diesseitig-Vergängliche), não é constitutivo para a obra. É por isso, também, que aqui aquele riso não ocupa uma posição central.

Existe apenas uma atitude secular que é incomparável com a de Shakespeare ou com a dos clássicos vienenses. Nela falta o riso dourado (das goldene Lächeln). Ela o desconhece porque nas obras desse movimento de arte esse outro, duradouro, o fato

\footnotetext{
${ }^{21}$ Sabe-se, hoje, que a pintura referida por Georgiades não é de autoria de Pieter Brueghel. Trata-se de uma cópia de autor desconhecido. A tela original de Brueghel foi perdida.
} 
religioso, não é capturado como válido, como estrutura. O indivíduo aqui é representado em dimensões enormes, gigantescas, e as relações mostradas com distorção. Seriedade não está presente, mas sim uma secura naturalista. Esta atitude pode também estar relacionada à necessidade de uma fuga romântica da realidade ou com um anseio por salvação.

Essa atitude nos encontra no século XIX, burguês, por exemplo, na música de Richard Wagner.

Os compositores criam, agora, a partir da esfera privada do sujeito. O privado, o burguês, a subjetividade configuram, entretanto, uma oposição ao publicamente válido, ao historicamente consagrado, obrigatoriamente encarnado na comunidade, assim, opondo-se também ao especificamente religioso. O novo meio significante musical não é mais o sacro imanente, como o era até a morte de Beethoven; por isso, a música religiosa comporta-se como um espelho profano, no qual se reflete a respectiva postura privada dos compositores frente à religião. Pode-se dizer, talvez, com uma formulação extremada que: se nas épocas antigas também as obras seculares eram consagradas, agora até mesmo aquelas que assumem (einnehmenden) a função religiosa são, elas próprias, "desconsagradas" (ungeweiht). De agora em diante, toda a música recebe, mesmo a religiosa, um traço profano. As obras religiosas dessa época são, no fundo, como que profanas, mesmo que dentre elas - eu penso, por exemplo, em Bruckner - possam ser encontradas abordagens ainda tão profundas, tão significativas sob o tema "Religião". Mas como agora, no novo meio significante, falta também a profundidade imanente da história, a memória da origem sacra, que caracteriza a música até a morte de Beethoven, as obras musicais não são mais capazes de fundir o microcosmo musical de "toda a realidade"; elas se isolam e tornam-se arte autônoma. É por isso que - ilegitimamente elas podem ser sentidas do ponto de vista privado-burguês como um substituto para a religião. Formou-se a opinião de que a função da música seria a de mergulhar em um estado de espírito puramente musical - "musicalmente puro": sustentado por uma música que era, na sua essência, estranha à linguagem e, ao mesmo tempo, estranha à religião. Chamou-se também essa música de "música absoluta" e seu - apenas aparente - contrário, "música programática". - A precipitação filosófica dessa atitude encontra-se em Schopenhauer. 
No presente, afinal, o compor manteve o caráter da busca por novos caminhos. Isso conduziu a um estreitamento de sua base. A música contemporânea torna-se cada vez mais apoiada por alguns grupos independentes, nos quais o interesse por essa busca é compartilhado com os compositores. Em vez de uma música vinculativa para todos, aparecem, mais que no passado, direções díspares. Os estratos mais amplos não estão ligados a nenhuma direção, porém a criação contemporânea deve se apresentar como eclética, e as tendências independentes devem aparecer desprovidas de vínculo. Intensificado no século XX através da incorporação das épocas pretéritas, o tratamento ampliado da música do passado fortalece a tendência ao ecletismo. Cada um pode escolher "sua" música, esteja ela dentro das tendências modernas ou da música do passado. Uma consciência musical única, auto evidente, comunitária e válida para todos, a base ampla, a raiz gerada ao longo de toda a história, a ancoragem integral no (elemento) sacro, tudo isso não está mais presente. Para o século XIX, constatamos um isolamento condicionado pelo colapso do privado e subjetivo. No século XX, o isolamento deslocase para os respectivos grupos musicais independentes, para os "movimentos" característicos daquele século. Esse isolamento - seja do indivíduo ou de um grupo - está intimamente relacionado a um senso exagerado de si mesmo e, ao mesmo tempo, se manifesta como falta de disposição (mangelnde Bereitschaft) para afirmar a realidade como uma totalidade, para nela sentir-se seguro e a partir dela criar-se algo. Nisso diferencia-se o tempo desde aproximadamente 1830 das épocas anteriores. - O isolamento é aquilo que se opõe ao sacro. No início, enfatizei a conexão entre a palavra sacra, o canto sacro e a comunidade genuína. E o profano apresentava-se como o musicalmente isolado, o independente.

É verdade que a autoconsciência dos grupos e movimentos no século XX está [também] ligada ao momento positivo, no qual o significado da comunidade é novamente descoberto. Mas esta, agora como em épocas anteriores, não é a condição, mas sim o alvo. 


\section{Aparições como os movimentos do Jugendbewegung ${ }^{22}$, o Singbewegung ${ }^{23}$, ou as aspirações pela renovação litúrgica ${ }^{24}$ são determinadas pelo anseio de retornar novamente}

${ }^{22}$ Jugendbewegung, termo que designa diversos movimentos de jovens que floresceram na Alemanha em períodos diferentes de sua história, da era Guilhermina (1871-1918) até o final do período de Weimar (1919-1933). Os autores especializados no estudo destes movimentos, como Walter Laqueur e Peter Stachura, costumam situar o movimento Wandervogel, cujas origens remontam ao final do século XIX, como a fonte histórica dos posteriores movimentos juvenis alemães dessas épocas. Trata-se de um legítimo termo guarda-chuva, que abarca movimentos pertencentes não só a momentos históricos distintos, como também movimentos pertencentes a diferentes posições ideológicas. Grosso modo, pode-se afirmar que, inicialmente, antes da Primeira Guerra, tratava-se essencialmente de grupos de jovens oriundos da pequenaburguesia alemã que buscavam se contrapor ao desencanto trazido pelo processo de modernização e industrialização da sociedade com atividades com caráter comunitário em contato com a natureza, principalmente montanhismo. Viam-se como grupos apolíticos. A partir da Primeira Guerra, com a proliferação de diferentes grupos e, principalmente, a partir da polarização política que seguiu o período do primeiro pós-guerra, passam a sofrer e a exercer influência mais explícita sobre grupos políticos organizados. A partir daí, existiram grupos juvenis atuantes politicamente atuantes com graus diversos de conservadorismo. Com a ascensão de Hitler ao poder, a partir já de 1934, o único grupo admitido oficialmente passa a ser o grupo oficial do NSDAP, o Hitlerjugend, sendo o movimento anterior praticamente extinto. É extremamente difícil extrair um núcleo ideológico comum uniforme à grande variedade de grupos que se costuma designar com o termo Jugendbewegung sem cairmos em simplificações grosseiras. Autores como Laqueur e Stachura, segundo Papathanassiou (2015), traçam a evolução e destacam as diferentes fases e características de atuação social e política de todos os diferentes grupos em questão, desde seus inícios, marcados pelo autonomismo e pelo neo-romantismo mais ingênuos, até seu desmantelamento e integração violenta pela Juventude Hitlerista. Talvez o traço básico capaz de fornecer uma visão unitária do fenômeno seja, como parece afirmar Georgiades, a pretensão de se construir uma vivência comunitária inspirada em um passado idealizado, em oposição ao individualismo e ao isolamento característicos da sociedade burguesa moderna. Contudo, os demais componentes ideológicos dos diferentes grupos de jovens, nos diferentes períodos da história, marcadamente aqueles afirmados pelos grupos mais ligados à extrema-direita, como o nacionalismo agressivo, a ideologia völkisch, o antiintelectualismo radical, o militarismo, etc. combinaram-se em diferentes formulações. Para um estudo que tenta reconstruir o tipo de relação mantida pelo movimento com a consciência histórica moderna, e que fornece uma visão atual das pesquisas sobre o tema, cf. Adriaansen (2015). Para uma leitura contemporânea e crítica com relação à sobrevivência de resquícios da afirmação idealizada da juventude e do ideário "comunitarista", que informaram esses movimentos, em nosso presente mais próximo e para além do contexto alemão, cf. Haroche (2004).

${ }^{23}$ Singbewegung é um termo que se refere ao ideário musical do Jugendbewegung nas décadas de 1920 e 1930, calcado principalmente na recusa dos ideais pedagógicos musicais burgueses. A valorização do canto coral, ou simplesmente do canto em uníssono em grupo, de repertório de canções folclóricas ou populares (Volkslieder) foi uma de suas principais características. Um histórico do papel ocupado pelo canto como meio pedagógico privilegiado na pedagogia musical alemã, cf. Kertz-Welzel (2004). Após a SegundaGuerra, resquícios desse ideário passam a ser localizáveis junto ao chamado Jugendmusikbewegung, movimento pedagógico musical mais organizado e que passa a exercer influência na reorganização da vida musical alemã. O grande crítico do Jugendmusikbewegung na década de 1950, e de sua revalorização da figura do músico amador ou diletante (Musikant) foi Theodor Adorno, principalmente em dois grandes textos de intervenção originados em debates com os principais proponentes do movimento, Kritik der Musikant (1956) e Zur Musikpädagogik (1957). Hoje, ambos os textos estão incluídos na coletânea Dissonâncias: música no mundo administrado, que faz parte do volume 14 de suas obras completas (Gesammelte Schriften). Cf. Adorno (1986). Para um comentário sobre a disputa entre Adorno e o Jugendmusikbewegung do segundo pós-guerra, cf. Vogt apud Klein et alli. (2019, p. 187-93).

${ }^{24}$ No original liturgischen Erneuerungbestrebungen. Ao final de seu livro Musik und Sprache, Georgiades se refere, mais especificamente, aos esforços dos monges beneditinos da abadia de Solesmes em recuperar a tradição do canto gregoriano, a partir do século XIX, no mesmo contexto que o dessa passagem. Tal esforço é visto, hoje, como um dos passos iniciais de um movimento mais amplo de renovação litúrgica que, após passar por diversas etapas, tanto na Igreja Católica, quanto na Igreja Protestante, culmina na reforma da liturgia católica no Concílio Vaticano II, em 1961. Para entendermos o sentido das colocações 
à comunidade. Portanto, não partia-se de uma comunidade pré-existente, desenvolvida, mas dos representantes dos movimentos encontrados ad hoc.

Nas aspirações litúrgicas de ambas as convicções, católica e evangélica - deixamos de fora aqui a grego-ortodoxas -, o desejo legítimo por uma participação mais ativa da comunidade conduz ao esforço de vincular, novamente, e com mais proximidade, a música à palavra sacra; ao esforço por uma música em um sentido mais estritamente litúrgico e ao mesmo tempo mais próxima do povo: o canto litúrgico uníssono nos idiomas nacionais, e assim em alemão. Nas épocas passadas, o estrato primário da linguagem litúrgica no Ocidente era a prosa latina. O canto litúrgico uníssono nas línguas nacionais não pode, portanto, derivar de qualquer tradição historicamente dada. Por sua vez, dentro do canto litúrgico uníssono, sente-se forçado a romper com os hábitos válidos nas missas de até então. O perigo do artístico está presente. Ele é composto pelo "querer fazer" uma comunidade. Mas, a comunidade é tão pouco "fabricável” quanto a palavra sacra é algo para ser inventado. A palavra (sacra) só foi instituída $u m a^{25}$ vez. A partir daí, ela formou a história e, por isso, nós só podemos recepcioná-la, em cada momento, sempre de modo novo. No entanto, isso vai de encontro aos esforços contemporâneos, na medida em que estes se apresentam como movimentos que preservam o isolamento. - É necessário que os grupos e movimentos que caracterizam o presente reconheçam seu lugar histórico - e isso requer que eles permaneçam enraizados no histórico. Eles devem encontrar em si mesmos a força para dissolver o sectarismo isolado, o amor-próprio, abrindo-se (aufzugehen) para toda a realidade. - Mas hoje tudo isso desmorona em tendências divergentes. Nesse todo estão contidos, tanto os esforços de renovação litúrgica, quanto a insistência das comunidades em manter o já encontrado anteriormente; tanto a necessidade de afirmar as obras do passado em sua totalidade, quanto o setor da criação livre, conforme dita o presente para aqueles que se sentem chamados; e, para além disso: tanto a necessidade de ancoragem no sacro, como, também, na hoje determinante

de Georgiades nesse momento de seu texto, faz-se necessário lembrar que uma das principais modificações trazidas pelo Concílio Vaticano II foi justamente a substituição da missa tridentina, rezada em latim e com canto gregoriano, para a missa e o canto litúrgico nas línguas vernáculas. Assim como no caso dos Jugendbewegung, o "movimento litúrgico", como ficou conhecido toda essa tendência de renovação dos ritos cristãos, foi impulsionado por um marcado ideário "comunitarista". Sobre a relação entabulada pelos movimentos juvenis das igrejas católicas e protestantes alemãs com os movimentos juvenis laicos no contexto do Jugendbewegung cf. Papathanassiou (2015). Torna-se claro, no próximo parágrafo, que é esse o contexto da reflexão de Georgiades aqui.

${ }^{25}$ Grifo no original. 
estrutura secular, de certo, profana. - Orientar o agir de acordo com esse todo, afirmá-lo como tal, parece ser uma exigência impossível. Apesar disso: o homem, como um ser intelectual (geistiges), isto é, como um ser histórico, dotado de memória histórica, sempre teve que atravessar a impossibilidade.

\section{Referências}

ADRIAANSEN, Robert-Jan. The Rhythm of Eternity: the German Youth Movement and the Experience of the Past, 1900-1933. New York; Oxford: Berghahn, 2015.

ADORNO, Theodor W. Gesammelte Schriften. Frankfurt am Main: Suhrkamp, 1986. Band 14.

GEORGIADES, Thrasybulos. Sakral und Profan in der Musik. München: Max Hueber, 1960.

GEORGIADES, Thrasybulos. Kleine Schriften. Tutzing: Hans Schneider, 1977.

HAROCHE, Claudine. "Subjetividades e aspirações: os movimentos de juventude na Alemanha (1918-1933)". Agora, v. VII, n. 2, 2004.

KERTZ-WELZEL, Alexandra. The Singing Muse? Three Centuries of Music Education in Germany. Journal of Historical Research in Music Education, v. 26, n. 1, 2004.

KLEIN, Richard; KREUZER, Johann Kreuzer; MÜLLER-DOOHM Stefan. Adorno Handbuch. Berlin: J. B. Metzler, 2019.

PAPATHANASSIOU, Maria. Secular and Christian Youth Associations in Interwar Germany: A Comparison of Public Life and Socio-Political Ideology. Paper delivered at Forms of Public Sociality: Collective Action, Collective Subjectivities and the State in the Twentieth Century, International Conference, 8-9 May 2015. University of Crete, Department of History \& Archaeology, Rethymno, Crete. Disponível em: https://www.academia.edu/37657964/Secular_and_Christian_Youth_Associations_in_Interwar_ Germany.pdf.

PELINSKI, Ramón. Uma breve introducción al pensamiento filosófico-musical de Thrasybulos Georgiades. Revista de Musicología. v. 38, n.1, 2015. 